Article

\title{
Activated Carbon from Spent Coffee Grounds: A Good Competitor of Commercial Carbons for Water Decontamination
}

\author{
Egle Rosson ${ }^{1}$, Francesco Garbo ${ }^{2}$, Giovanni Marangoni ${ }^{1}$, Roberta Bertani ${ }^{1}$, \\ Maria Cristina Lavagnolo ${ }^{2}$, Elisa Moretti ${ }^{3} \mathbb{D}$, Aldo Talon $^{3}$, Mirto Mozzon ${ }^{1}$ and \\ Paolo Sgarbossa ${ }^{1, * \text { (D) }}$
}

1 Department of Industrial Engineering (DII), University of Padova, Via Marzolo 9, 35131 Padova, Italy; egle.rosson@phd.unipd.it (E.R.); giovanni.marangoni@unipd.it (G.M.); roberta.bertani@unipd.it (R.B.); mirto.mozzon@unipd.it (M.M.)

2 Department of Civil, Architectural and Environmental Engineering (DICEA), University of Padova, Via Marzolo 9, 35131 Padova, Italy; francesco.garbo.2@phd.unipd.it (F.G.); mariacristina.lavagnolo@unipd.it (M.C.L.)

3 Department of Molecular Sciences and Nanosystems, Ca' Foscari University of Venice-Scientific Campus, Via Torino 155/b, 30172 Mestre Venice, Italy; elisam@unive.it (E.M.); aldair@unive.it (A.T.)

* Correspondence: paolo.sgarbossa@unipd.it; Tel.: +39-049-827-5733

Received: 14 July 2020; Accepted: 11 August 2020; Published: 12 August 2020

Featured Application: Activated carbon from a renewable source (spent coffee grounds) as a competitive substitute for commercial ones in water decontamination from phenols.

\begin{abstract}
In the framework of the circular economy, spent coffee grounds were converted into powdered activated carbon by means of pyrolysis, using potassium hydroxide as the activating agent. Its adsorption capacity on a panel of phenolic compounds was compared with those of two commercial powdered activated carbons, after preliminary studies on organic dyes with different ionic properties, to assess the affinity between adsorbates and adsorbents. Pseudo-first-order and pseudo-second-order kinetic models were carried out, together with Freundlich and Langmuir isotherms. They were useful to calculate the breakthrough at 5\%,10\%, and 50\% of adsorption and the partition coefficients for the comparison of performance between different sorbent systems in a less biased manner (e.g., reducing bias associated with operational settings like sorbate concentration and sorbents dosage). The results showed that the removal efficiency for SCGs-AC was comparable with that of the commercial activated carbons with the highest partition coefficients for methylene blue $(12,455 \mathrm{mg} / \mathrm{g} / \mu \mathrm{M}$, adsorption capacity $=179 \mathrm{mg} / \mathrm{g})$ and 3-chlorophenol $(81.53 \mathrm{mg} / \mathrm{g} / \mu \mathrm{M}$, adsorption capacity $=3765 \mathrm{mg} / \mathrm{g}$ ). The lower efficiency in bromothymol blue and bisphenol-A adsorption was due to its different morphology and surface properties.
\end{abstract}

Keywords: emerging micropollutants; phenolic compounds; organic dyes; spent coffee grounds up-cycling; activated carbon from spent coffee grounds; adsorption on powdered activated carbons

\section{Introduction}

Industrialization, urbanization, and increased consumer demand are responsible for a continuous spread in the production of chemical substances. According to Gavrilescu et al. [1], the global production of chemicals grew from 1 million (in 1930) to nearly 350 million tons per year (in 2011). In 2012, approximately 143,000 new compounds were registered in the European market, $50 \%$ of them being harmful to the environment [2]. Chemical compounds can be released in the environment during production, storage, 
transportation, use, and disposal, thus polluting the air, soil, and water [3]. Among others, micropollutants are of big concern as they pose a serious risk to the environmental integrity and human health. According to the United States Environmental Protection Agency (US EPA) [4], micropollutants are chemical compounds with-out a regulatory status and whose impacts on human health and the environment are still unknown. They include pharmaceuticals (i.e., anti-inflammatory drugs, lipid regulators, antibiotics, neuroactive compounds, etc.) and personal care products (PCPs) such as fragrances, disinfectants, UV filters, and insect repellents [5,6]. Both pharmaceuticals and PCPs constitute 70\% of the total amount of micropollutants found in the environment. The remaining $30 \%$ is composed of industrial chemicals such as pesticides, food additives, phthalates, polychlorobiphenyls (PCBs), per-fluorinated alkyl sulfonate (PFAS) compounds, fire retardants, plasticizers, insecticides, and fungicide [2]. Micropollutants can be found in surface waters, groundwater, and wastewaters in low concentration, from $\mathrm{ng} / \mathrm{L}$ to $\mu \mathrm{g} / \mathrm{L}[3,7]$. Conventional wastewater treatment plants are not designed to remove such pollutants; therefore, many of them are not eliminated and may be directly discharged in the aquatic environment [8]. Once in the environment, micropollutants concentration tends to decrease due to dilution, biodegradation, sorption into sediments, volatilization, dispersion, redox reactions, and photodegradation [9]. However, the rate of these processes is low due to their high chemical stability and their constant release into the environment [9].

Among micropollutants, phenolic compounds play a primary role, as they are widely present in coking residues, papers, gases, oil-refining wastes, industrial wastewaters, and landfill leachates [10-13]. Phenol $(\mathrm{Ph})$ is widely used as precursor for the production of plastics, herbicides, phenolic resins, and pharmaceutical drugs. It is also used in disinfectants, peptizing agents, extracting solvents, and lubricants [14]. 3-Chlorophenol (CP) is used as a wood preservative, antirust agent, pesticide, and in paper, biocide, cosmetic, and public health industries [15]. Moreover, it can be formed during the degradation of phenoxy herbicides and the chlorination of effluents containing phenolic compounds [16]. Bisphenol-A (BPA) is an emerging pollutant, included in the European list of "substances of very high concern" and suspected to cause breast cancer [17], mainly used as intermediate in the production of polycarbonate, epoxy resins, and flame retardants $[18,19]$. Moreover, it can be found in many products, as adhesives, protective coatings, powder paints, and building materials. Its annual global production exceeds 3.8 million tons [20]. Furthermore, BPA can easily react with sodium hypochlorite giving chlorinated derivatives in disinfection water supply systems, which have been detected in humans where they interfere with estrogenic activity [19]. Rodriguez-Narvaez et al. [21] reviewed the most common techniques for the removal of emerging contaminants in water, with a special focus on adsorption as in Jeirani et al. [6]. The latter was considered in different studies to manage wastewaters and aqueous solutions contaminated by phenolic compounds [22-24].

Activated carbons are prepared by physical or chemical activation of relatively inexpensive materials such as lignite, coal, peat, and wood [25]. Even carbonaceous materials with high carbon content and low inorganic amount might be used [26]. Many kinds of food waste, agro-waste, and agricultural products have been studied as low-cost precursors, as they are available in large amounts and could be considered renewable resources from a circular economic approach [27-31]. Among them, spent coffee grounds (SCGs) may represent a valuable option [32-36]. They and the derived activated carbon has been successfully used to remove phenol from aqueous solutions [37-39], while the removal of CP and BPA has yet been only partially investigated [40,41].

The goal of this research is to evaluate the removal efficiency of phenol, chlorophenol, and bisphenol-A by means of adsorption on powdered activated carbons (PACs) from spent coffee grounds. Adsorption performances were compared with those of two commercial activated carbons. Prior to tests with phenolic compounds, preliminary studies were performed to assess the adsorption of three organic dyes characterized by different ionic properties: methylene blue (MB)-cationic, erythrosine- $\mathrm{B}$ (EB)-anionic, and bromothymol blue (BB)-non-ionic. These experiments were useful to compare the results with the literature data and to evaluate the affinity between adsorbent and adsorbate. 


\section{Materials and Methods}

\subsection{Powdered Activated Carbons}

Three different PACs (one from SCGs and two commercial PACs) were used to study the adsorption of organic dyes and phenolic compounds. SCGs (100\% Arabica blend) were collected from an Italian local cafeteria after espresso coffee brewing. They were sieved to remove impurities, stirred to obtain a homogenous sample, and oven-dried at $105^{\circ} \mathrm{C}$ for $24 \mathrm{~h}$. Hereafter, $60 \mathrm{~g}$ were mixed with potassium hydroxide $(\mathrm{KOH})$ powder in a 1:1 mass ratio under $\mathrm{N}_{2}$ atmosphere. $\mathrm{KOH}$ is commonly used as activating agent to develop porosity during thermal treatments [42]. The obtained mixture was pyrolyzed in a tubular alumina reactor (Carbolite) at $800^{\circ} \mathrm{C}$ for $4 \mathrm{~h}$, under $\mathrm{N}_{2}$ atmosphere $(150 \mathrm{cc} / \mathrm{min})$. The operating conditions were chosen according to Wang et al. [43]. After pyrolysis, the sample was washed with deionized water on a Gooch filter 4, until neutral $\mathrm{pH}$ was reached, and oven-dried at $105^{\circ} \mathrm{C}$ for $24 \mathrm{~h}$. The obtained PAC sample is called SCGs-AC in this work. The commercial PACs were purchased from Merck (Product ID 1.02514.1000, Darmstadt, Germany) and Ceca Italiana S.R.L., Arkema Group (Acticarbone NCL 1240, Rho (MI), Italy), here labelled C1-AC and C2-AC, respectively, and used as received.

\subsection{Batch Adsorption Experiments}

\subsubsection{Organic Dyes}

Methylene blue (MB, MM $319.86 \mathrm{~g} / \mathrm{mol}$ ), erythrosine B (EB, MM $879.84 \mathrm{~g} / \mathrm{mol}$ ), and bromothymol blue (BB, MM $624.40 \mathrm{~g} / \mathrm{mol}$ ) were purchased from Sigma-Aldrich and used as received. Tests were carried out in 100-mL flasks, sealed with a plastic tarp, by adding fixed amounts of PACs to aqueous solutions containing a known initial concentration of organic dyes (Table 1). The samples were continuously stirred at $800 \mathrm{rpm}$ at ambient temperature $\left(20 \pm 2{ }^{\circ} \mathrm{C}\right)$, keeping the $\mathrm{pH}$ between 5 and 6 . The experimental conditions were chosen according to Ahmad et al. (2007) [44]. Samples were collected at different time intervals, filtered with a PTFE $0.45-\mu \mathrm{m}$ syringe filter, and analyzed to calculate the adsorption capacity according to Equation (1), and the adsorption kinetics using a pseudo-first-order (Equation (2)) or pseudo-second-order kinetic models (Equation (3)) [45]. The tests, conducted in triplicate, were stopped when the measured concentration was constant after two consecutive measurements, or it was below the detection limits.

$$
\text { Adsorption capacity }(\%)=\frac{C_{i}-C_{t}}{C_{i}} \times 100
$$

where $C_{i}(\mathrm{in} \mathrm{mg} / \mathrm{L})$ is the initial concentration and $C_{t}(\mathrm{in} \mathrm{mg} / \mathrm{L})$ is the concentration at time $t$.

$$
\begin{gathered}
\ln \left(q_{e}-q_{t}\right)=\ln \left(q_{e}\right)-k_{1} t \\
\frac{t}{q_{t}}=\frac{1}{k_{2} q_{e}^{2}}+\frac{t}{q_{e}}
\end{gathered}
$$

where $q_{e}$ and $q_{t}$ represent the amount of the adsorbed compounds $(\mathrm{mg} / \mathrm{g})$ at equilibrium and at time $t$ $(h)$, respectively; $k_{1}\left(\mathrm{~h}^{-1}\right)$ is the first-order kinetic constant, and $k_{2}$ is the one for pseudo-second-order kinetic $(\mathrm{g} / \mathrm{mg} \cdot \mathrm{h})$.

Table 1. Batch adsorption tests experimental conditions for organic dyes and phenolic compounds.

\begin{tabular}{ccccccc}
\hline Parameters & MB & EB & BB & Ph & CP & BPA \\
\hline $\begin{array}{c}\text { Initial solutions } \\
\text { concentration }(\mathrm{g} / \mathrm{L})\end{array}$ & 0.02 & 0.025 & 0.1 & 0.2 & 0.2 & 0.025 \\
PACs dosage $(\mathrm{g} / \mathrm{L})$ & 0.5 & 1 & 5 & 1 & 1 & 0.0125 \\
\hline
\end{tabular}


For a fair comparison of the adsorption capacity of each material and to leverage the effect of the experimental conditions (i.e., initial loading concentration) the partition coefficient (PC) was calculated according to the Equation (4) [46-49]

$$
P C\left(\text { in } \frac{m g}{g} / \mu M\right)=\frac{\text { Adsorption capacity }(\text { in } m g / g)}{\text { Final adsorbate concentration }(\mu M)}
$$

\subsubsection{Phenolic Compounds}

Phenol (Ph, MM $94.11 \mathrm{~g} / \mathrm{mol}$ ), 3-Chlorophenol (CP, MM $128.56 \mathrm{~g} / \mathrm{mol}$ ), and Bisphenol-A (BPA, MM $228.29 \mathrm{~g} / \mathrm{mol}$ ) were purchased from Sigma-Aldrich and used as received. Adsorption tests on phenols were performed according to ASTM D3860-98 [50]. They were carried out in 100-mL flasks, sealed with a plastic tarp, by adding fixed amounts of PACs to aqueous solutions containing a known initial concentration of phenolic compounds (Table 1). The samples were continuously stirred at $800 \mathrm{rpm}$, at ambient temperature $\left(20 \pm 2{ }^{\circ} \mathrm{C}\right)$, keeping the $\mathrm{pH}$ between 5 and 6 . The experimental conditions were chosen according to Laksaci et al. [37,38] and Zbair et al. [51]. Samples were collected after 5, 20, 60, and $180 \mathrm{~min}$ from the beginning of the tests, filtered with a PTFE $0.45 \mu \mathrm{m}$ syringe filter, and analyzed to calculate the adsorption capacity, according to Equation (1), and the adsorption kinetics (Equations (2) and (3)). The tests were conducted in triplicate.

\subsection{Equilibrium Isotherms}

Determination of adsorption isotherms was performed according to ASTM D3860-98 [50] by adding different amounts of PACs to a series of $100 \mathrm{~mL}$ flasks, containing the same initial concentration used in the batch adsorption tests for both organic dyes and phenolic compounds (Table 1). The flasks were kept under stirring in a six-place magnetic plate at $800 \mathrm{rpm}$ and room temperature $\left(20 \pm 2{ }^{\circ} \mathrm{C}\right)$ until equilibrium, keeping the $\mathrm{pH}$ between 5 and 6 . Freundlich and Langmuir models were considered in this study, as they are the most frequently used to describe the adsorption of organic dyes and phenolic compounds [52-55], even if other models have been considered in the literature [56]. The parameters in the Freundlich (Equation (5)) and Langmuir (Equation (6)) equations were determined through a linearization procedure.

$$
\begin{aligned}
\ln q_{e} & =\ln k_{F}+\frac{1}{n} \ln C_{e}(\text { linearized Freundlich) } \\
\frac{C_{e}}{q_{e}} & =\frac{1}{k_{L} Q_{0}}+\frac{C_{e}}{Q_{0}} \text { (linearized Langmuir) }
\end{aligned}
$$

where $q_{e}$ is the adsorption capacity $(\mathrm{mg} / \mathrm{g}), C_{e}$ is the residual concentration, $k_{F}$ and $1 / \mathrm{n}$ are the Freundlich constants, $k_{L}$ is the Langmuir constant, and $Q_{0}$ is the maximum saturation capacity at the isotherm temperature $(\mathrm{mg} / \mathrm{g})$.

\subsection{Analytical Procedures}

The specific surface area (SSA), total pore volume (TPV), and average pore diameter (APD) of the PACs were calculated with the Brunauer-Emmett-Teller (BET) method by recording $\mathrm{N}_{2}$ adsorption-desorption isotherms at $-196{ }^{\circ} \mathrm{C}$ on an automatic adsorption instrument (Micromeritics apparatus, ASAP 2010 V4.01 G, Norcross, Georgia, USA). The morphology and the elemental composition of the samples were determined with environmental scanning electron microscopy energy dispersive $\mathrm{x}$-ray analysis (ESEM-EDX) on a FEI-QUANTA200 instrument (FEI Italia S.r.l., Milan, Italy). The chosen blow-up was 2000X for elemental composition and 400X and 1600X for morphology. The PACs skeletal density was measured by a helium pycnometer (Multivolume Pycnometer 1305 by Micromeritics, Norcross, Georgia, GA, USA). Finally, the point of zero charge (pH-PZC) was calculated using the solid addition method reported in Kumar et al. (2008) [57]. $50 \mathrm{~mL}$ of $0.1 \mathrm{M} \mathrm{KNO}_{3}$ solution were prepared adding dropwise a $0.1 \mathrm{M} \mathrm{HCl}$ or $0.1 \mathrm{M} \mathrm{NaOH}$ solution to get different $\mathrm{pH}$ values $(2,4,6,8,10$, and 12). Then, $1.0 \mathrm{~g}$ of 
PACs was added in each solution and the samples were kept under stirring (800 rpm) in a six places magnetic plate for $48 \mathrm{~h}$ at room temperature $\left(20 \pm 2{ }^{\circ} \mathrm{C}\right)$. The final $\mathrm{pH}$ of the supernatant was recorded. The difference between the initial and the final $\mathrm{pH}\left(\Delta \mathrm{pH}=\mathrm{pH}_{\mathrm{i}}-\mathrm{pH}_{\mathrm{f}}\right)$ was plotted against the initial $\mathrm{pH}$ value $\left(\mathrm{pH}_{\mathrm{i}}\right)$. The $\mathrm{pH}-\mathrm{PZC}$ is the point in which the resulting curve intersects the $\mathrm{x}$ axis $\Delta \mathrm{pH}=0$.

Organic dyes and BPA concentrations were measured using a UV/VIS spectrometer (PerkinElmer instruments, Lambda 25 UV/VIS Spectrometer, Milan, Italy), keeping a constant wavelength at maximum absorbance ( $664 \mathrm{~nm}$ for MB, $526 \mathrm{~nm}$ for EB, $433 \mathrm{~nm}$ for BB, and $224 \mathrm{~nm}$ for BPA). Ph and CP were determined using a UV-VIS spectrophotometer (Shimadzu Italia S.r.l. UV-1601, Milan, Italy) at a constant wavelength of $510 \mathrm{~nm}$, according to the Italian analytical standard IRSA-CNR 29/2003, vol. 2, n. 5070-A2 [58]. The $\mathrm{pH}$ of each sample was adjusted to 4 with concentrated phosphoric acid, and $5 \mathrm{~mL}$ of copper sulphate were added. The samples were distilled for $10 \mathrm{~min}$ and the condensed solutions were collected. Then, $5 \mathrm{~mL}$ of ammonium chloride were added to each solution, then ammonium hydroxide until $\mathrm{pH}=10$. Finally, by mixing the solutions with $2 \mathrm{~mL}$ of 4 -aminoantipyrene and $2 \mathrm{~mL}$ of potassium ferrocyanide for $10 \mathrm{~min}$, the color was developed. The volumes were brought to $200-250 \mathrm{~mL}$ with deionized water before UV-VIS analyses. All concentrations have been determined by extrapolation from calibration curves obtained from standard solution of the target compounds, according to the Beer-Lambert law.

\section{Results and Discussion}

\subsection{Physico-Chemical Properties of PACs}

The porous nature of the samples was investigated by $\mathrm{N}_{2}$ physisorption at $-196^{\circ} \mathrm{C}$. All of them displayed very high surface area values, of 823 and $932 \mathrm{~m}^{2} / \mathrm{g}$ for the commercial C1-AC and C2-AC, respectively, up to $1199 \mathrm{~m}^{2} / \mathrm{g}$ for SCGs-AC, prepared by spent coffee grounds treated with $\mathrm{KOH}$ and then pyrolyzed at high temperature. In particular, the latter sample showed a $30 \%$ higher BET surface area with respect to the commercial active carbons used for comparison. The cumulative pore volume of the three sample was comparable and very high, in the range $0.491-0.523 \mathrm{~cm}^{3} / \mathrm{g}$. According to the IUPAC classification [59], the mean pore diameter was borderline between micro- and mesopore regions for SCGs-AC (1.7 nm) and typical of mesoporous materials for C1-AC and C2-AC (2.5 nm and $2.1 \mathrm{~nm}$, respectively).

It is well established that the adsorption characteristics of activated carbons derive from the nature of the precursor, production method, and experimental conditions during the preparation. Thus, they are recognized as versatile adsorbents due to their high specific surface area, porosity, high adsorption capacities, and surface properties [42]. In particular, the $\mathrm{pH}-\mathrm{PZC}$ values of the activated carbons here considered, calculated using the solid addition method reported by Kumar et al. [57], ranged in the interval 8.8-10.5 (Table 2). Activated carbons are amphoteric materials in which surface charges depend on the $\mathrm{pH}$ of the solution. As an example, SCGs-AC sample displayed a pH-PZC of 9.5, which gave rise to a negative charge on the surface of the activated carbon for $\mathrm{pH}$ values higher than the $\mathrm{pH}-\mathrm{PZC}$, with an electrostatic interaction between the negatively charged surface of the AC and a cationic molecule. As the $\mathrm{pH}$ of the system decreases, the number of positive charges on the surface increases, and the surface sites on the activated carbon do not tend to absorb the cations of dye due to electrostatic repulsion. An inverted mechanism occurs in the presence of an anionic probe molecule, with stronger electrostatic interactions at acidic $\mathrm{pH}$ values and repulsive interactions in strong alkaline conditions when the $\mathrm{pH}$ is higher than the $\mathrm{pH}-\mathrm{PZC}$ of the material. All the adsorption determinations here reported have been carried out at $\mathrm{pH}$ about 6 , thus reducing the negative charge amount on the AC surface in the order C2-AC $>$ SCGs-AC $>$ C1-AC.

ESEM-EDX was applied to observe the morphology and pore size of PACs and to determine their composition. Figure 1a,b illustrate 1600X and 400X magnified ESEM micrographs of SCGs-AC sample. The surface was smooth, full of cavities and characterized by partially flattened cylindrical pores. In the pores, traces of foreign elements (i.e., $\mathrm{Mg}$, $\mathrm{Al}$, $\mathrm{Si}$ or $\mathrm{S}, \leq 1 \% \mathrm{w} / \mathrm{w}$ ) could be observed. The morphology is 
quite similar to that reported by Laksaci [38], where the pores observed ( $\mu \mathrm{m}$ range) act as channels for the microporous network. The textural features of the commercial samples, observed from micrographs in Figure $1 c-f$, were significantly different from those obtained for the SCGs-AC sample. These images showed the extent of inhomogeneity of the surfaces of C1-AC and C2-AC, which displayed a more compact and less porous structure compared to the adsorbent generated from spent coffee grounds.

Table 2. Powdered activated carbons (PACs) characterization parameters. ${ }^{1}$.

\begin{tabular}{|c|c|c|c|c|c|c|}
\hline Sample & $\mathrm{SSA}\left(\mathrm{m}^{2} / \mathrm{g}\right)$ & $\operatorname{TVP}\left(\mathrm{cm}^{3} / \mathrm{g}\right)$ & APD (nm) & $\begin{array}{l}\text { Density } \\
\left(\mathrm{g} / \mathrm{cm}^{3}\right)\end{array}$ & pH-PZC & $\operatorname{EDX}\left({ }_{w / w} \%\right)^{2}$ \\
\hline SCGs-AC & 1199 & 0.502 & 1.67 & 1.78 & 9.5 & $\begin{array}{l}\text { C: } 85.3 \\
\text { O: } 13.7\end{array}$ \\
\hline C1-AC & 823 & 0.523 & 2.54 & 1.81 & 8.8 & $\begin{array}{l}\text { C: } 89.3 \\
\text { O: } 8.6\end{array}$ \\
\hline $\mathrm{C} 2-\mathrm{AC}$ & 932 & 0.491 & 2.10 & 1.96 & 10.5 & $\begin{array}{l}\text { C: } 91.5 \\
\text { O: } 7.2\end{array}$ \\
\hline
\end{tabular}

${ }^{1} \mathrm{SSA}=$ specific surface area, $\mathrm{TPV}=$ total pore volume, $\mathrm{APD}=$ average pore diameter, $\mathrm{pH}-\mathrm{PZC}=$ point of zero charge. ${ }^{2}$ From ESEM analyses.
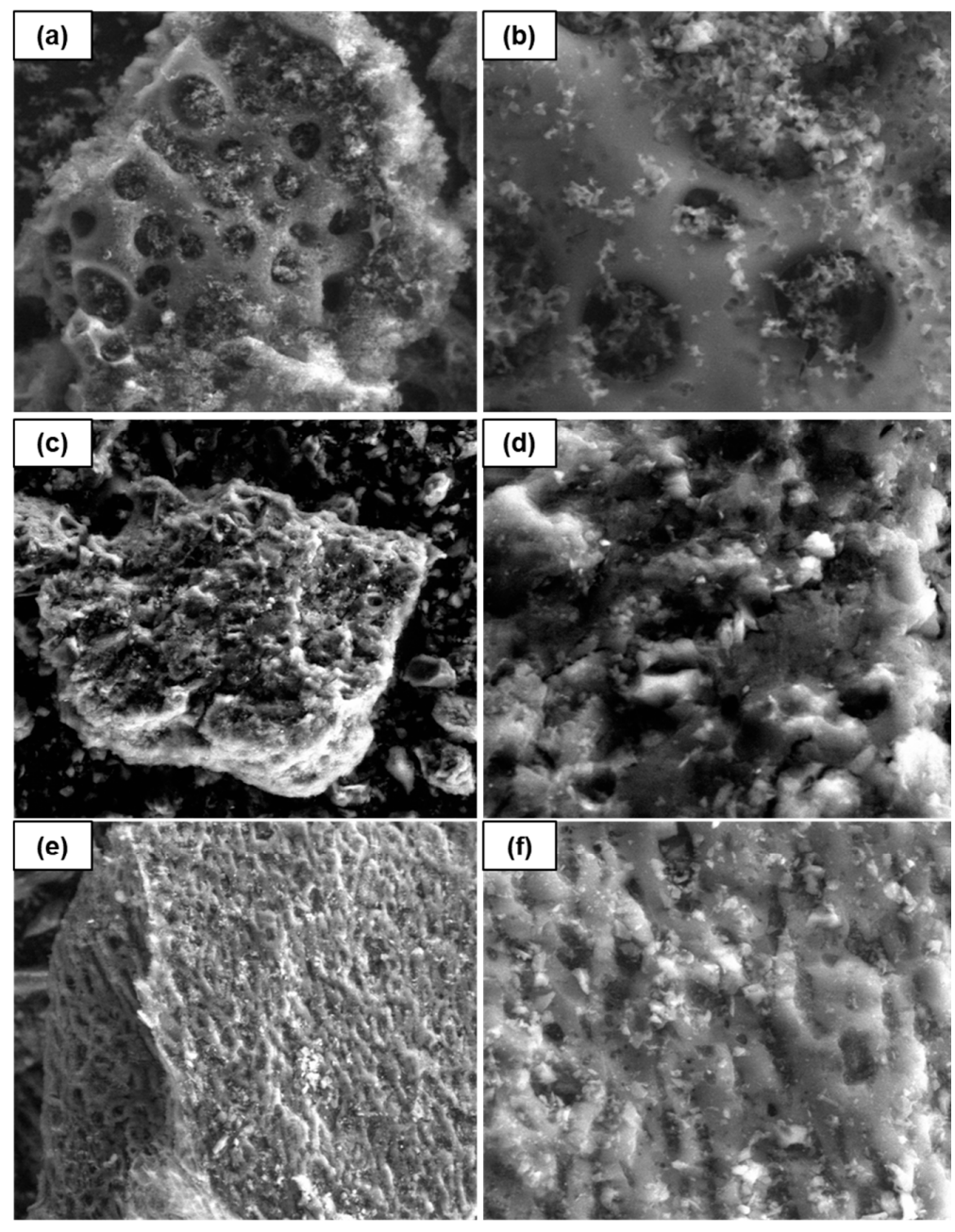

$100 \mu \mathrm{m}$

$30 \mu \mathrm{m}$

Figure 1. Environmental scanning electron microscopy (ESEM) images for (a) SCGs-AC at 400X; (b) SCGs-AC at 1600X; (c) C1-AC at 400X; (d) C1-AC at 1600X; (e) C2-AC at 400X; (f) C2-AC at 1600X.

By comparing the ESEM-EDX elemental composition of the three samples (Table 2), it emerged that SCGs-AC contained a much higher amount of oxygen with respect to the commercial materials 
(C/O ratio 6.23 for SCGs-AC; 10.38 for C1-AC and 12.72 for C2-AC), which could be reasonably due to the peculiar preparation process carried out through $\mathrm{KOH}$ activation. Since adsorption of a dye onto adsorbents is also a physical phenomenon in which dye molecules attach onto the adsorbent surface under the influence of van der Waals forces and hydrogen bonding, the presence of a higher amount of oxygen species in the adsorbent matrix could be advantageous for the adsorption of cationic dyes, such as methylene blue, and detrimental in the presence of anionic organic molecules, such as erythrosine-B [35,60].

\subsection{Adsorption Tests}

\subsubsection{Organic Dyes Removal}

Adsorption tests on organic dyes were performed as preliminary studies with the aim of evaluating the affinity between PACs and adsorbates with different ionic properties. Adsorption occurred in a two-stage process, with a steep initial phase until $5 \mathrm{~min}$ for MB (Figure 2a) and $20 \mathrm{~min}$ for EB and BB (Figure 2b,c), as a result of the high concentration gradient. The only exception was for BB with C2-AC, whose trend continuously increased over time, reaching a plateau after approximately $2 \mathrm{~h}$ of contact time. It is usually reported that, at the beginning of the adsorption process, the filling of PACs pores is predominant, resulting in a marked removal rate (Figure 2). Once the pores volume has been filled, chemisorption is the driving force, whose intensity is proportional to the number of active sites in PACs surfaces [42]. The adsorption trends were confirmed by the results of the kinetic modelling (Table 3). The processes followed the pseudo-second-order kinetic in which the adsorption was proportional to the gradient squared (Equation (3)). Similar results were observed by Laksaci et al. [37], who performed adsorption tests on MB, and by Anastopoulos et al. [35], who reviewed the use of coffee as adsorbent for dyes and heavy metals in wastewaters.

Table 3. Details of PACs pseudo-second-order kinetic model (best fitting) for organic dyes and phenolic compounds. ${ }^{1}$.

\begin{tabular}{|c|c|c|c|c|c|c|c|}
\hline Sample & Details & MB & EB & BB & $\mathbf{P h}$ & $\mathrm{CP}$ & BPA \\
\hline \multirow{3}{*}{ SCGs-AC } & \multirow{3}{*}{$\begin{array}{c}\mathrm{q}_{\mathrm{e}} \\
\text { Kinetic } \\
\text { constant } \\
\mathrm{R}^{2}\end{array}$} & 40 & 24.8 & 19.8 & 143 & 194 & 116 \\
\hline & & 3.13 & 0.223 & 0.005 & 0.815 & 0.266 & 0.007 \\
\hline & & 0.9989 & 0.9955 & 0.9905 & 1 & 1 & 0.9969 \\
\hline \multirow{3}{*}{ C1-AC } & \multirow{3}{*}{$\begin{array}{c}\mathrm{q}_{\mathrm{e}} \\
\text { Kinetic } \\
\text { constant } \\
\mathrm{R}^{2}\end{array}$} & 40 & 25 & 20 & 122 & 190 & 175 \\
\hline & & 1.04 & 0.727 & 8.33 & 0.338 & 0.278 & 0.014 \\
\hline & & 0.9998 & 0.9983 & 1 & 1 & 1 & 0.9998 \\
\hline \multirow{3}{*}{ C2-AC } & \multirow{3}{*}{$\begin{array}{c}\mathrm{qe} \\
\text { Kinetic } \\
\text { constant } \\
\mathrm{R}^{2}\end{array}$} & 40 & 25 & 20 & 151 & 196 & 200 \\
\hline & & 8.93 & 0.471 & 0.238 & 0.441 & 0.521 & 0.005 \\
\hline & & 1 & 0.9992 & 0.9975 & 1 & 1 & 0.9997 \\
\hline
\end{tabular}

${ }^{1}$ The reported data are related to the average of triplicate measurements; the standard deviations were always less than $5 \%$; $\mathrm{q}_{\mathrm{e}}$ in $\mathrm{mg} / \mathrm{g}$ and kinetic constant, calculated according to Equation (3), in $\mathrm{g} / \mathrm{mg} / \mathrm{min}$.

All PACs showed higher adsorption capacities for ionic adsorbates (Figure 2) as MB and EB. In particular, $\mathrm{C} 2-\mathrm{AC}$ presented always an intermediate removal rate with respect to SCGs-AC and C1-AC. SCGs-AC and C2-AC was the best PAC for MB adsorption, achieving 100\% removal in 5 min of contact time (Table 4). With regard to EB, the removal rate of SCGs-AC was lower than those of C1-AC and C2-AC. However, the results were comparable if $180 \mathrm{~min}$ of adsorption time were considered (Table 4). Since the kinetics of adsorption could be affected by the appropriate surface functional groups of the matrix to attract the adsorbate molecule, it was suggested that the higher amount of 
oxygen species present in the SCGs-AC sample (as determined by ESEM-EDX, Table 2) could create a wider series of van der Waals interactions and hydrogen capable of attracting more rapidly MB.
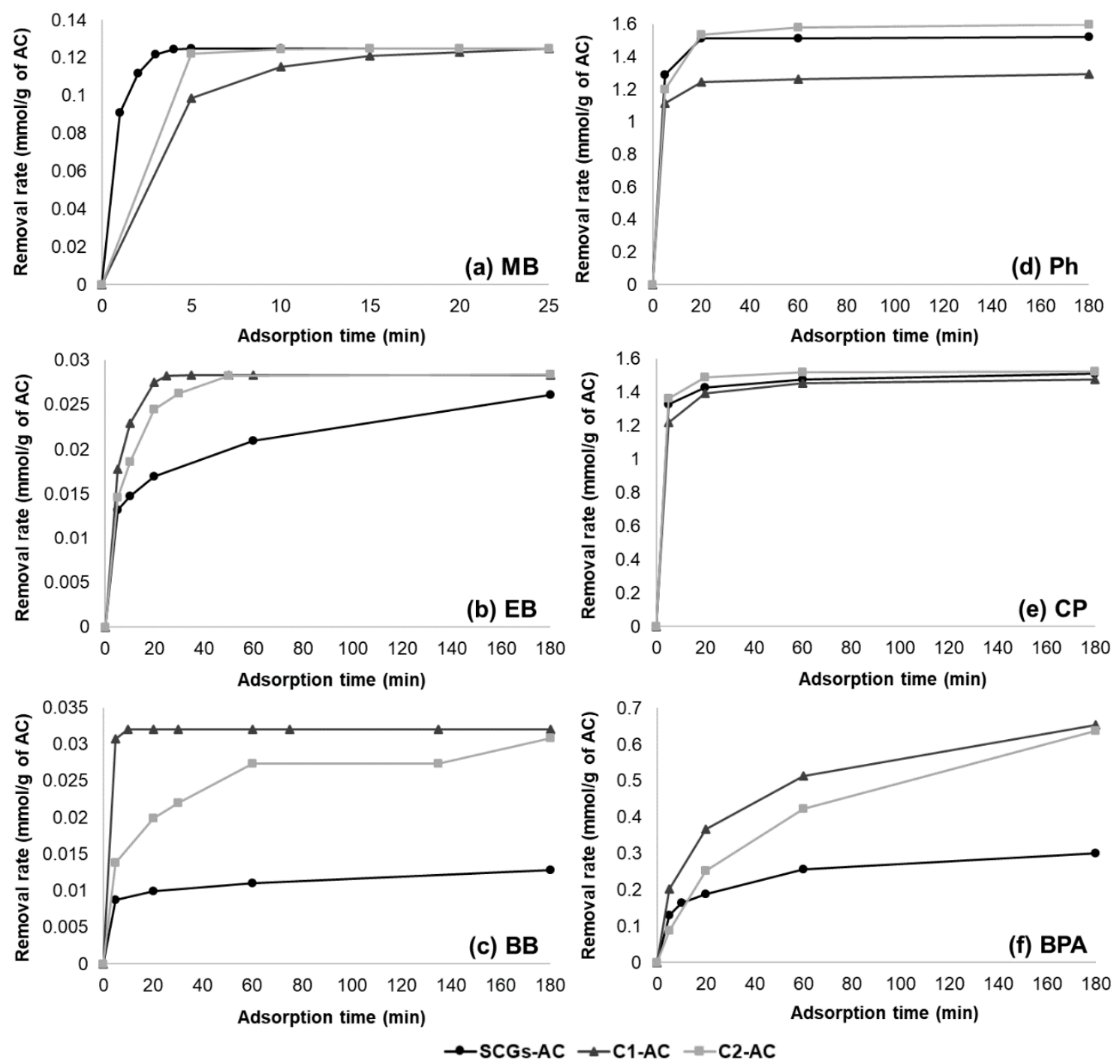

Figure 2. Removal rate ( $\mathrm{mmol} / \mathrm{g}$ of $\mathrm{AC}$ ) during adsorption (min) for organic dyes and phenolic compounds. The reported data are the average of triplicate measurements; the standard deviations were always less than $5 \%$. The adsorption time data for MB are reported until $25 \mathrm{~min}$ to see clearly the adsorption trend, because it is faster than the others.

The results of the adsorption isotherms (Table 5) showed that the equilibrium could be satisfactorily described by the Langmuir model, indicating a monolayer coverage onto char particles for commercial PACs and for SCGs-AC only with MB, as already reported by Spagnoli et al. [61]. Freundlich was the best fitting model for EB and BB with SCGs-AC. There are numerous reports on organic molecules adsorption in pores that are barely large enough to admit the adsorbate molecule and it has been pointed out that dyes and humic acids have a size $(1.5-3.0 \mathrm{~nm})$ that favors their adsorption in mesopores (i.e., pore diameter $>2 \mathrm{~nm}$ ) [62]. Hence, the difference in pore size distribution can significantly affect the adsorption capacity for molecules of different sizes and shapes. For this reason, it is important to know the molecular dimensions of the pollutant adsorbate and ensure that the activated carbon used has sufficient pore diameter to achieve the removal of the adsorbate. Regarding the MB, EB, and BB molecules, they all have smaller molecular sizes (lower than $1.5 \mathrm{~nm}$ ) compared with the average pore diameter of the active carbons used (Table 2). 
Table 4. Experimental adsorption capacity (\%) of PACs at fixed time for organic dyes and phenolic compounds. ${ }^{1}$

\begin{tabular}{cccccccc}
\hline Sample & Adsorption Time (min) & MB & EB & BB & Ph & CP & BPA \\
\hline \multirow{3}{*}{ SCGs-AC } & 5 & 100 & 46.3 & 27.2 & 60.6 & 85.4 & 14.9 \\
& 20 & 100 & 59.7 & 31.1 & 71.2 & 91.9 & 21.5 \\
& 60 & 100 & 73.8 & 34.4 & 71.3 & 94.8 & 29.3 \\
& 180 & 100 & 92.0 & 39.9 & 71.5 & 97.0 & 34.4 \\
C1-AC & 5 & 80.8 & 62.7 & 96.0 & 52.4 & 78.3 & 23.1 \\
& 20 & 98.5 & 96.8 & 100 & 58.4 & 89.7 & 41.8 \\
& 60 & 100 & 100 & 100 & 59.4 & 93.5 & 58.5 \\
C2-AC & 180 & 100 & 100 & 100 & 60.8 & 94.8 & 74.7 \\
& 5 & 97.8 & 51.4 & 43.4 & 56.3 & 87.5 & 10 \\
& 20 & 100 & 86.0 & 62.2 & 72.2 & 95.6 & 28.9 \\
& 60 & 100 & 99.8 & 85.4 & 74.3 & 97.7 & 48.2 \\
\hline
\end{tabular}

${ }^{1}$ The reported data are the average of triplicate measurements; the standard deviations were always less than $5 \%$.

Table 5. Details of PACs adsorption isotherms for organic dyes and for phenolic compounds. ${ }^{1}$.

\begin{tabular}{|c|c|c|c|c|c|c|c|}
\hline Sample & & MB & EB & BB & $\mathbf{P h}$ & $\mathrm{CP}$ & BPA \\
\hline \multirow{6}{*}{ SCGs-AC } & \multirow{3}{*}{$\begin{array}{c}\text { Model } \\
\text { Equations }\end{array}$} & Langmuir & Freundlich & Freundlich & Freundlich & Freundlich & Langmuir \\
\hline & & $y=0.0056$ & $y=1.6429$ & $y=10.04 x$ & $y=2.5548$ & $y=2.1638$ & $y=0.0045$ \\
\hline & & $x+0.0025$ & $x-1.5483$ & -40.232 & $x-4.9972$ & $x-3.1231$ & $x+0.0005$ \\
\hline & \multirow{2}{*}{ Parameters } & $\mathrm{Q}_{0}=179$ & $\mathrm{n}=0.609$ & $\mathrm{n}=0.100$ & $\mathrm{n}=0.391$ & $\mathrm{n}=0.462$ & $\mathrm{Q}_{0}=222$ \\
\hline & & $\mathrm{k}_{\mathrm{L}}=2.24$ & $\mathrm{k}_{\mathrm{F}}=0.213$ & $\begin{array}{c}\mathrm{k}_{\mathrm{F}}= \\
3.11 \cdot 10^{-18}\end{array}$ & $\mathrm{k}_{\mathrm{F}}=0.007$ & $\mathrm{k}_{\mathrm{F}}=0.044$ & $\mathrm{k}_{\mathrm{L}}=9.00$ \\
\hline & $\mathrm{R}^{2}$ & 0.9894 & 0.9731 & 0.9021 & 0.9129 & 0.9029 & 0.9658 \\
\hline \multirow{6}{*}{ C1-AC } & \multirow{3}{*}{$\begin{array}{c}\text { Model } \\
\text { Equations }\end{array}$} & Langmuir & Langmuir & Langmuir & Freundlich & Freundlich & Langmuir \\
\hline & & $y=0.0036$ & $y=0.0062$ & $\mathrm{y}=0.0039$ & $y=3.4639$ & $\mathrm{y}=1.2778$ & $y=0.0079$ \\
\hline & & $x+0.0006$ & $x+0.0132$ & $x+0.0449$ & $x-10.379$ & $x+0.399$ & $x+0.0026$ \\
\hline & \multirow{2}{*}{ Parameters } & $\mathrm{Q}_{0}=278$ & $\mathrm{Q}_{0}=161$ & $\mathrm{Q}_{0}=256$ & $\mathrm{n}=0.289$ & $\mathrm{n}=0.783$ & $\mathrm{Q}_{0}=127$ \\
\hline & & $\mathrm{k}_{\mathrm{L}}=6.00$ & $\mathrm{k}_{\mathrm{L}}=0.470$ & $\mathrm{k}_{\mathrm{L}}=0.087$ & $\begin{array}{c}\mathrm{k}_{\mathrm{F}}= \\
3.11 \cdot 10^{-5}\end{array}$ & $\mathrm{k}_{\mathrm{F}}=1.49$ & $\mathrm{k}_{\mathrm{L}}=3.04$ \\
\hline & $R^{2}$ & 0.9972 & 0.9609 & 0.9152 & 0.9118 & 0.9099 & 0.9956 \\
\hline \multirow{6}{*}{ C2-AC } & Model & Langmuir & Langmuir & Langmuir & Freundlich & Freundlich & Langmuir \\
\hline & \multirow{2}{*}{ Equations } & $y=0.0085$ & $y=0.0119$ & $y=0.0129$ & $y=1.6268$ & $y=0.8865$ & $y=0.0032$ \\
\hline & & $x+0.0036$ & $x+0.0177$ & $x+0.096$ & $x-1.2875$ & $x+2.3257$ & $x+9 \cdot 10^{-5}$ \\
\hline & \multirow{2}{*}{ Parameters } & $\mathrm{Q}_{0}=118$ & $\mathrm{Q}_{0}=84.0$ & $\mathrm{Q}_{0}=77.5$ & $\mathrm{n}=0.615$ & $\mathrm{n}=1.13$ & $\mathrm{Q}_{0}=313$ \\
\hline & & $\mathrm{k}_{\mathrm{L}}=2.36$ & $\mathrm{k}_{\mathrm{L}}=0.672$ & $\mathrm{k}_{\mathrm{L}}=0.134$ & $\mathrm{k}_{\mathrm{F}}=0.276$ & $\mathrm{k}_{\mathrm{F}}=10.2$ & $\mathrm{k}_{\mathrm{L}}=35.6$ \\
\hline & $\mathrm{R}^{2}$ & 0.9952 & 0.9617 & 0.9701 & 0.9067 & 0.9640 & 0.9929 \\
\hline
\end{tabular}

To meaningfully evaluate the performance of the sorbents, PC values have been calculated and reported in Table 6 together with breakthrough levels at $5 \%, 10 \%$, and $50 \%$ of adsorption based on the adsorption isotherms.

It is clear from the data reported in Table 6 that high adsorption capacities do not directly correlate to high PCs since the latter take into account also the residual concentration of pollutant. In general, the PCs of all the PACs considered are high for the dyes compared with the phenolic compounds, while the adsorption capacities have an opposite trend. An improvement in PC values implies enhancement in adsorption affinity: thus, the affinity of SCGs-AC for MB was significantly higher with respect $\mathrm{C} 1-\mathrm{AC}$ and $\mathrm{C} 2-\mathrm{AC}$, in agreement with the surface properties of the ACs. Coherently, SCGs-AC exhibited a significantly lower affinity for EB and BB. The extremely high value of PC for $\mathrm{C} 1-\mathrm{AC}$ for $\mathrm{BB}$ could be considered in agreement with the extremely rapid adsorption rate observed in Figure 2. As for 3-chlorophenol (CP), the SCGs-AC shows both higher adsorption capacity ( $3765 \mathrm{mg} / \mathrm{g}$ ) and partition coefficient $(81.53 \mathrm{mg} / \mathrm{g} / \mu \mathrm{M})$ than the commercial PACs, representing and interesting candidate as compared with recent systems proposed in the literature (e.g., Batool et al. [56] report for 2,4-dichlorophenol a maximum adsorption capacity of $45.95 \mathrm{mg} / \mathrm{g}$ and $\mathrm{PC}=41.77 \mathrm{mg} / \mathrm{g} / \mu \mathrm{M}$ ). 
Table 6. Experimental concentrations, breakthrough levels at 5\%,10\%, and 50\% of adsorption, adsorption capacities at saturation (in $\mathrm{mg} / \mathrm{g}$ ), and partition coefficients.

\begin{tabular}{|c|c|c|c|c|c|c|c|c|}
\hline Sample & Parameter & U.M. & MB & EB & BB & Ph & $\mathrm{CP}$ & BPA \\
\hline \multirow{7}{*}{ SCGs-AC ${ }^{1}$} & $C_{i}$ & $\mathrm{mg} / \mathrm{L}$ & 20 & 25 & 100 & 200 & 200 & 25 \\
\hline & $\mathrm{C}_{\mathrm{f}}$ & $\mathrm{mg} / \mathrm{L}$ & 0.005 & 0.224 & 0.885 & 57 & 5.94 & 10.5 \\
\hline & $\mathrm{q}_{\mathrm{e}}(\mathrm{BT} 5 \%)$ & $\mathrm{mg} / \mathrm{g}$ & 174.89 & 38.66 & 201.77 & 4711.0 & 3765.5 & 220.97 \\
\hline & $\mathrm{q}_{\mathrm{e}}(\mathrm{BT} 10 \%)$ & $\mathrm{mg} / \mathrm{g}$ & 174.67 & 35.38 & 117.50 & 4102.6 & 3349.6 & 220.91 \\
\hline & $\mathrm{q}_{\mathrm{e}}(\mathrm{BT} 50 \%)$ & $\mathrm{mg} / \mathrm{g}$ & 171.35 & 13.48 & 0.329 & 912.40 & 938.55 & 220.04 \\
\hline & Adsorption capacity & $\mathrm{mg} / \mathrm{g}$ & 179 & 42.1 & 337 & 5371 & 3765 & 222 \\
\hline & Partition coefficient & $\mathrm{mg} / \mathrm{g} / \mu \mathrm{M}$ & 12455 & 165.55 & 237.72 & 8.87 & 81.53 & 4.82 \\
\hline \multirow{7}{*}{$\mathrm{C} 1-\mathrm{AC}^{1}$} & $\mathrm{C}_{\mathrm{i}}$ & $\mathrm{mg} / \mathrm{L}$ & 20 & 25 & 100 & 200 & 200 & 25 \\
\hline & $\mathrm{C}_{\mathrm{f}}$ & $\mathrm{mg} / \mathrm{L}$ & 0.020 & 0.058 & 0.005 & 78.3 & 10.4 & 3.10 \\
\hline & $\mathrm{q}_{\mathrm{e}}(\mathrm{BT} 5 \%)$ & $\mathrm{mg} / \mathrm{g}$ & 275.58 & 147.76 & 228.37 & 2386.3 & 1211.9 & 125.27 \\
\hline & $\mathrm{q}_{\mathrm{e}}(\mathrm{BT} 10 \%)$ & $\mathrm{mg} / \mathrm{g}$ & 275.45 & 147.09 & 227.01 & 1979.1 & 1131.1 & 125.17 \\
\hline & $\mathrm{q}_{\mathrm{e}}(\mathrm{BT} 50 \%)$ & $\mathrm{mg} / \mathrm{g}$ & 273.44 & 137.58 & 208.15 & 258.93 & 533.91 & 123.74 \\
\hline & Adsorption capacity & $\mathrm{mg} / \mathrm{g}$ & 278 & 161 & 256 & 2850 & 1294 & 127 \\
\hline & Partition coefficient & $\mathrm{mg} / \mathrm{g} / \mu \mathrm{M}$ & 4365.6 & 2433.2 & 31968 & 3.42 & 16.00 & 9.37 \\
\hline \multirow{7}{*}{$\mathrm{C} 2-\mathrm{AC}^{1}$} & $\mathrm{C}_{\mathrm{i}}$ & $\mathrm{mg} / \mathrm{L}$ & 20 & 25 & 100 & 200 & 200 & 25 \\
\hline & $\mathrm{C}_{\mathrm{f}}$ & $\mathrm{mg} / \mathrm{L}$ & 0.036 & 0.046 & 0.175 & 49.5 & 4.09 & 1.36 \\
\hline & $\mathrm{q}_{\mathrm{e}}($ BT $5 \%)$ & $\mathrm{mg} / \mathrm{g}$ & 115.43 & 79.05 & 71.86 & 1400.2 & 1059.7 & 312.63 \\
\hline & $\mathrm{q}_{\mathrm{e}}($ BT $10 \%)$ & $\mathrm{mg} / \mathrm{g}$ & 115.29 & 78.79 & 71.57 & 1282.4 & 1010.2 & 312.61 \\
\hline & $\mathrm{q}_{\mathrm{e}}(\mathrm{BT} 50 \%)$ & $\mathrm{mg} / \mathrm{g}$ & 113.20 & 75.06 & 67.44 & 493.11 & 600.50 & 312.30 \\
\hline & Adsorption capacity & $\mathrm{mg} / \mathrm{g}$ & 118 & 84 & 78 & 1522 & 1109 & 313 \\
\hline & Partition coefficient & $\mathrm{mg} / \mathrm{g} / \mu \mathrm{M}$ & 1056.8 & 1611.4 & 278.92 & 2.89 & 34.88 & 52.39 \\
\hline
\end{tabular}

\subsubsection{Phenolic Compounds Removal}

At $\mathrm{pH}$ about 6 all the phenols considered are in the protonated form ( $\mathrm{pKa}=9.89,9.12$, and 9.6-10.2 for $\mathrm{Ph}, \mathrm{CP}$, and $\mathrm{BPA}$, respectively), thus the adsorption performance of the $\mathrm{AC}$ are reasonably due to a complex series of van der Waals and steric interactions.

Similarly, to the behavior of organic dyes, adsorption for Ph and $\mathrm{CP}$ occurred in a two-stage process with all the tested PACs (Figure 2d,e). After 20 min of contact time, the equilibrium was almost established, reaching a reduction of $71.2 \%$ for Ph and $91.9 \%$ for CP with SCGs-AC, of $58.4 \%$ for Ph and $89.7 \%$ for $\mathrm{CP}$ with $\mathrm{C} 1-\mathrm{AC}$, and of $72.2 \%$ for $\mathrm{Ph}$ and $95.6 \%$ for $\mathrm{CP}$ with C2-AC (Table 4 ). As regards $\mathrm{BPA}$, the adsorption curves (Figure 2f) continuously increased without reaching the equilibrium in $3 \mathrm{~h}$ of contact time. According with Çeçen and Aktaş [63], adsorption processes longer than $3 \mathrm{~h}$ are not technically and economically convenient in real applications, so the tests were stopped after such duration.

In agreement with what was observed for organic dyes and according to the literature [64], the pseudo-second-order kinetic was the best fitting model also for phenols' adsorption (Table 3). The kinetic constants were higher in the adsorption of Ph and CP for all PACs, with respect BPA confirming the trends reported in Figure 2. Freundlich isotherms could be used for describing the adsorption of $\mathrm{Ph}$ and $\mathrm{CP}$ for all the PACs as reviewed by Hussain et al. [29], while the Langmuir model was more suitable for BPA as confirmed by Zbair et al. [47].

It is to observe that considering the adsorption capacities and the PC values, the same trends were obtained only for Ph (SCGs > C1-AC > C2-AC). As for CP, the higher performance was demonstrated by SCGs-AC either considering the adsorption capacity or the PC values, while the behavior of C1-AC and $\mathrm{C} 2-\mathrm{Ac}$ resulted to be inverted considering the two different parameters. As for BPA, SCGs have lower performance with respect $\mathrm{C} 2-\mathrm{AC}$ in both cases, the latter being the best adsorbent after $3 \mathrm{~h}$ of contact time (Table 4).

In general, the adsorption capacity of PACs was higher for $\mathrm{CP}$ without any noticeable difference between the three adsorbents (Figure 2e). The removal rates of both Ph and CP for SCGs-AC and C2-AC were comparable (about $140 \mathrm{mg} / \mathrm{g}$ ), while those for C1-AC were lower (approximately $120 \mathrm{mg} / \mathrm{g}$ ). Similar results were obtained for phenolic compounds by Laksaci et al. [37,38], Castro et al. [32], 
and even better than those described by Lamine et al. [64]. The same considerations could not be extended to SCGs-AC with BPA.

According to Pendleton et al. [65], the trend of BPA adsorption capacity is inversely related to the oxygen content of the adsorbents (Table 2). Fonseca Alves et al. [64] gained $98 \%$ of BPA removal with AC from SCGs activated with $\mathrm{ZnCl}_{2}$, under the same $\mathrm{pH}$ and temperature conditions of the reported study, even if he adsorption time was $24 \mathrm{~h}$ ( $3 \mathrm{~h}$ in this experiment). Better results could be found in the literature with other adsorbents, as reviewed by Bhatnagar and Anastopoulos [40]. In particular, ultra-high-surface-area porous AC from low cost asphalt seemed to be effective for the removal of both BPA and other endocrine disrupting chemicals from wastewater [66]. Techniques other than adsorption are available for BPA removal, including ozonation [67], membrane filtration [68], plasma [69], and advance oxidation processes [70]. Despite the high efficiency, all these techniques are characterized by high investment and operational costs, as opposed to adsorption processes [71]. The lower removal efficiency of SCGs-AC for BPA could be due to the morphology and to a poor electrostatic interaction established between BPA, which was reported to be in its neutral form at $\mathrm{pH}$ below 8 [72] and the partially negatively charged SCGs-AC surface.

\section{Conclusions}

Emerging pollutants pose a severe risk for the ecosystems and the human health, since they are continuously released into the environment. Among them, phenolic compounds play an important role being widely used in industrial applications. In this study, three different PACs were used to remove phenolic compounds after preliminary analyses on organic dyes. All the samples displayed very high surface area values, ranging from about $820 \mathrm{~m}^{2} \mathrm{~g}^{-1}$ to $1200 \mathrm{~m}^{2} \mathrm{~g}^{-1}$. In particular, the sample SCGs-AC, prepared by spent coffee grounds treated with $\mathrm{KOH}$ and then pyrolyzed at high temperature, showed a 30\% higher surface area value with respect the commercial active carbons used for comparison purposes. Moreover, the mean pore diameter was between micro- and mesopore regions for this sample and typical of mesoporous materials for the commercial ones. Adsorption occurred via multiple mechanisms, including pore filling and adsorbent-adsorbate $\pi-\pi$ and H-bonding interactions. SCGs-AC proved to have similar adsorption capacities than commercial PACs for the removal of organic dyes and phenolic compounds. In particular, PACs showed higher affinity with ionic substances, as $\mathrm{MB}$ and $\mathrm{EB}$, as confirmed by the high partition coefficients and in agreement with their surface properties. Regarding Ph and CP, the removal rate was around $70 \%$ and $95 \%$ for all PACs. BPA was harder to remove from solution in comparison to the other phenolic compounds, with the lowest value of PC for SCGs-AC. Future studies will be aimed at improving the chemical properties of the produced SCGs-AC, via surface functionalization, to obtain a higher removal efficiency for phenolic compounds and other endocrine-disrupting agents. Moreover, LCA and LCC studies will be carried out to evaluate whether this application could be feasible from both the environmental and economical point of view at larger scale.

Author Contributions: Conceptualization, R.B. and P.S.; methodology, R.B., P.S., E.M., and A.T.; investigation, E.R., F.G., M.M. and G.M.; resources, R.B., M.C.L., E.M., and A.T.; data curation, E.R., F.G., G.M., E.M., and A.T.; writing - original draft preparation, E.R. and F.G.; writing-review and editing, E.R., P.S., R.B., E.M., and A.T.; supervision, R.B., P.S., and M.C.L.; project administration, R.B.; funding acquisition, R.B. and M.M. All authors have read and agreed to the published version of the manuscript.

Funding: This research was funded by the Department of Industrial Engineering (DII), University of Padova, TWINNING-2017 research project "Supramolecular transition-metal architectures based on non-covalent interactions for selective molecular sorption and non-linear optics: Rational design and preparation."

Acknowledgments: Authors wish to thank CEASC (University of Padova) for ESEM analyses.

Conflicts of Interest: The authors declare no conflict of interest. 


\section{References}

1. Gavrilescu, M.; Demnerová, K.; Aamand, J.; Agathos, S.; Fava, F. Emerging pollutants in the environment: Present and future challenges in biomonitoring, ecological risks and bioremediation. New Biotech. 2015, 32, 147-156. [CrossRef] [PubMed]

2. Das, S.; Ray, N.M.; Wan, J.; Khan, A.; Chakraborty, T.; Ray, M.B. Micropollutants in Wastewater: Fate and Removal Processes. In Physico-Chemical Wastewater Treatment and Resource Recovery; Farooq, R., Ahmad, Z., Eds.; IntechOpen: London, UK, 2017; pp. 75-107. [CrossRef]

3. Luo, Y.; Guo, W.; Ngo, H.H.; Nghiem, L.D.; Hai, F.H.; Zhang, J.; Liang, S.; Wang, X.C. A review on the occurrence of micropollutants in the aquatic environment and their fate and removal during wastewater treatment. Sci. Total Environ. 2014, 473-474, 619-641. [CrossRef] [PubMed]

4. US EPA. 2019. Contaminants of Emerging Concern including Pharmaceuticals and Personal Care Products. Available online: https://www.epa.gov/wqc/contaminants-emerging-concern-including-pharmaceuticalsand-personal-care-productsa (accessed on 7 February 2020).

5. Ebele, A.J.; Abdallah, M.A.; Harrad, S. Pharmaceuticals and personal care products (PPCPs) in the freshwater aquatic environment. Emerg. Contam. 2017, 3, 1-16. [CrossRef]

6. Jeirani, Z.; Hui Niu, C.; Soltan, J. Adsorpion of emerging pollutants on activated carbon. Rev. Chem. Eng. 2017, 33, 491-522. [CrossRef]

7. Schwarzenbach, R.P.; Escher, B.I.; Fenner, K.; Hofstetter, T.B.; Johnson, C.A.; von Guten, U.; Wehrli, B. The Challenge of Micropollutants in Aquatic Systems. Science 2006, 313, 1072-1077. [CrossRef]

8. Bolong, N.; Ismail, A.F.; Salim, M.R.; Matsuura, T. A review of the effects of emerging contaminants in wastewater and options for their removal. Desalination 2009, 239, 229-246. [CrossRef]

9. Pal, A.; Yew-Hoong Gin, K.; Yu-Chen Lin, A.; Reinhard, M. Impacts of emerging organic contaminants on freshwater resources: Review of recent occurrences, sources, fate and effects. Sci. Total Environ. 2010, 408, 6062-6069. [CrossRef]

10. Fu, Y.; Shen, Y.; Zhang, Z.; Ge, X.; Chen, M. Activated bio-chars derived from rice husk via one and two-step KOH-catalyzed pyrolysis for phenol adsorption. Sci. Total Environ. 2019, 646, 1567-1577. [CrossRef]

11. Kim, J.H.; Hong, S.; Sun, H.J.; Ha, S.; Kim, J. Precipitated and chemically-crosslinked laccase over polyaniline nanofiber for high performance phenol sensing. Chemosphere 2016, 143, 142-147. [CrossRef]

12. Cañizares, P.; Carmona, M.; Bazara, O.; Delgado, A.; Rodrigo, M.A. Adsorption equilibrium of phenol onto chemically modified activated carbon F400. J. Hazard. Mater. 2006, B131, 243-248. [CrossRef]

13. Mohd Din, A.T.; Hameed, B.H.; Ahmad, A.L. Batch adsorption of phenol onto physiochemical-activated coconut shell. J. Hazard. Mater. 2009, 161, 1522-1529. [CrossRef]

14. Busca, G.; Berardinelli, S.; Resini, C.; Arrighi, L. Technologies for the removal of phenol from fluid streams: A short review of recent developments. J. Hazard. Mater. 2008, 160, 265-288. [CrossRef]

15. Wang, S.L.; Tzou, Y.M.; Lu, Y.H.; Sheng, G. Removal of 3-chlorophenol from water using rice-straw-based carbon. J. Hazard. Mater. 2007, 147, 313-318. [CrossRef] [PubMed]

16. Mallek, M.; Chtourou, M.; Portillo, M.; Monclús, H.; Walha, K.; ben Salah, A.; Salvadó, V. Granulated cork as biosorbent for the removal of phenol derivatives and emerging contaminants. J. Environ. Manag. 2018, 223, 576-585. [CrossRef] [PubMed]

17. Lassouane, F.; Äit-Amar, H.; Amrani, S.; Rodriguez-Couto, S. A promising laccase immobilization approach for Bisphenol A removal from aqueous solutions. Bioresour. Technol. 2019, 271, 360-367. [CrossRef] [PubMed]

18. Russo, G.; Barbato, F.; Mita, D.G.; Grumetto, L. Occurrence of Bisphenol A and its analogues in some foodstuff marketed in Europe. Food Chem. Toxicol. 2019, 131, 110575. [CrossRef]

19. Zhou, Y.; Chen, M.; Zhao, F.; Mu, D.; Zhang, Z.; Hu, J. Ubiquitous Occurrence of Chlorinated Byproducts of Bisphenol A and Nonylphenol in Bleached Food Contacting Papers and Their Implications for Human Exposure. Environ. Sci. Technol. 2015, 49, 7218-7226. [CrossRef]

20. Michalowicz, J. Bisphenol A-Sources, toxicity and biotransformation. Environ. Toxicol. Pharmacol. 2014, 37, 738-758. [CrossRef]

21. Rodriguez-Narvaez, O.M.; Peralta-Hernandez, J.M.; Goonetilleke, A.; Bandala, E.R. Treatment technologies for emerging contaminants in water: A review. Chem. Eng. J. 2017, 323, 361-380. [CrossRef]

22. Hao, Z.; Wang, C.; Yan, Z.; Jiang, H.; Xu, H. Magnetic particles modification of coconut shell-derived activated carbon and biochar for effective removal of phenol from water. Chemosphere 2018, 211, 962-969. [CrossRef] 
23. Kumar, A.; Jena, H.M. Removal of methylene blue and phenol onto prepared activated carbon from Fox nutshell by chemical activation in batch and fixed-bed column. J. Clean. Prod. 2016, 137, 1246-1259. [CrossRef]

24. Mailler, R.; Gasperi, J.; Coquet, Y.; Derome, C.; Buleté, A.; Vulliet, E.; Bressy, A.; Varrault, G.; Chebbo, G.; Rocher, V. Removal of emerging micropollutants from wastewater by activated carbon adsorption: Experimental study of different activated carbons and factors influencing the adsorption of micropollutants in wastewater. J. Environ. Chem. Eng. 2016, 4, 1102-1109. [CrossRef]

25. Ahmadpour, A.; Do, D.D. The preparation of active carbons from coal by chemical and physical activation. Carbon 1996, 34, 471-479. [CrossRef]

26. Alcañiz-Monge, J.; Illán-Gómez, M.J. Insight into hydroxides-activated coals: Chemical or physical activation? J. Colloid. Interface Sci. 2008, 318, 35-41. [CrossRef]

27. Lee, C.; Hong, S.; Hong, S.; Choi, J.; Park, S. Production of Biochar from Food Waste and its Application for Phenol Removal from Aqueous Solution. Water Air Soil Pollut. 2019, 230, 70. [CrossRef]

28. Sindhu, R.; Gnansounou, E.; Rebello, S.; Binod, P.; Varjani, S.; Shekhar Thakur, I.; Nair, R.B.; Pandey, A. Conversion of food and kitchen waste to value-added products. J. Environ. Manag. 2019, 241, 619-630. [CrossRef]

29. Hussain, S.; Anjali, K.P.; Towhida Hassan, S.; Dwivedi, P.B. Waste tea as novel adsorbent: A review. Appl. Water Sci. 2018, 8, 165. [CrossRef]

30. Rovani, S.; Censi, M.T.; Pedrotti, S.L., Jr.; Lima, E.C.; Cataluña, R.; Fernandes, A.N. Development of a new adsorbent from agro-industrial waste and its potential use in endocrine disruptor compound removal. J. Hazard. Mater. 2014, 271, 311-320. [CrossRef]

31. Ioannidou, O.; Zabaniotou, A. Agricultural residues as precursors for activated carbon production-A review. Renew. Sustain. Energy Rev. 2007, 11, 1966-2005. [CrossRef]

32. Castro, C.S.; Abreu, A.L.; Silva, C.L.T.; Guerreiro, M.C. Phenol adsorption by activated carbon produced from spent coffee grounds. Water Sci. Technol. 2011, 64, 2059-2065. [CrossRef]

33. Kemp, K.C.; Baek, S.B.; Lee, W.; Meyyappan, M.; Kim, K.S. Activated carbon derived from waste coffee grounds for stable methane storage. Nanotechnology 2015, 26, 385-602. [CrossRef] [PubMed]

34. Jung, K.; Choi, B.H.; Hwang, M.; Jeong, T.; Ahn, K. Fabrication of granular activated carbons derived from spent coffee grounds by entrapment in calcium alginate beads for adsorption of acid orange 7 and methylene blue. Bioresour. Technol. 2016, 219, 185-195. [CrossRef] [PubMed]

35. Anastopoulos, I.; Karamesouti, M.; Mitropoulos, A.C.; Kyzas, G.Z. A review for coffee adsorbents. J. Mol. Liq. 2017, 229, 555-565. [CrossRef]

36. Naga Babu, A.; Srinivasa Reddy, D.; Suresh Kumar, G.; Ravindhranath, K.; Krishna Mohan, G. Removal of lead and fluoride from contaminated water using exhausted coffee grounds based bio-sorbent. J. Environ. Manag. 2018, 218, 602-612. [CrossRef]

37. Laksaci, H.; Khelifi, A.; Belhamdi, B.; Trari, M. Valorization of coffee grounds into activated carbon using physic-chemical activation by $\mathrm{KOH} / \mathrm{CO}_{2}$. J. Environ. Chem. Eng. 2017, 5, 5061-5066. [CrossRef]

38. Laksaci, H.; Khelifi, A.; Trari, M.; Addoun, A. Synthesis and characterization of microporous activated carbon from coffee grounds using potassium hydroxides. J. Clean. Prod. 2017, 147, 254-262. [CrossRef]

39. Popovici, D.; Dusescu, C.; Neagu, M. Removal of phenol from aqueous solutions on activated carbon obtained from coffee grounds. Rev. Chim. 2016, 67, 751-756. [CrossRef]

40. Bhatnagar, A.; Anastopoulos, I. Adsorptive removal of bisphenol A (BPA) from aqueous solution: A review. Chemosphere 2017, 168, 885-902. [CrossRef]

41. Ahsan, A.; Islam, T.; Imam, M.A.; Golam Hyder, A.H.M.; Jabbari, V.; Dominguez, N.; Noveron, J.C. Biosorption of bisphenol-A and sulfamethoxazole from water using sulfonated coffee waste: Isotherm, kinetic and thermodynamic studies. J. Environ. Chem. Eng. 2018, 6, 6602-6631. [CrossRef]

42. Galanakis, C.M. Handbook of Coffee Processing By-Products: Sustainable Applications; Elsevier Inc.: Amsterdam, The Netherlands, 2017.

43. Wang, C.; Wen, W.; Hsu, H.; Yao, B. High-capacitance $\mathrm{KOH}$-activated nitrogen-containing porous carbon material from waste coffee grounds in supercapacitor. Adv. Powder Technol. 2016, 27, 1387-1395. [CrossRef]

44. Ahmad, A.L.; Loh, M.M.; Aziz, J.A. Preparation and characterization of activated carbon from oil palm wood and its evaluation on Methylene blue adsorption. Dyes Pigment 2007, 75, 263-272. [CrossRef]

45. Ho, Y.S.; McKay, G. A comparison of chemisorption kinetic models applied to pollutant removal on various sorbents. Process Saf. Environ. Prot. 1998, 76, 332-340. [CrossRef] 
46. Kim, K.H.; Szulejko, J.E.; Raza, N.; Kumar, V.; Vikrant, K.; Tsang, D.C.W.; Bolan, N.S.; Ok, Y.S.; Khan, A. Identifying the best materials for the removal of airborne toluene based on performance metrics-A critical review. J. Clean. Prod. 2019, 241, 118408. [CrossRef]

47. Vikrant, K.; Kim, K.H. Nanomaterials for the adsorptive treatment of $\mathrm{Hg}(\mathrm{II})$ ions from water. Chem. Eng. J. 2019, 358, 264-282. [CrossRef]

48. Younis, S.A.; Motawea, E.A.; Moustafa, Y.M.; Lee, J.; Kim, K.H. A strategy for the efficient removal of chlorophenols in petrochemical wastewater by organophilic and aminated solica@alginate microbeads: Taguchi optimization and isotherm modeling based on partition coefficient. J. Hazard. Mat. 2020, 397, 122792. [CrossRef]

49. Vikrant, K.; Kim, K.H.; Szulejko, J.E. The retrograde adsorption phenomenon at the onset of breakthrough and its quantitation: An experimental case study for gaseous toluene on activated carbon surface. Environ. Res. 2019, 178, 108737. [CrossRef]

50. ASTM. ASTM D3860-98(2014): Standard Practice for Determination of Adsorptive Capacity of Activated Carbon by Aqueous Phase Isotherm Technique; ASTM: West Conshohocken, PA, USA, 1998.

51. Zbair, M.; Bottlinger, M.; Ainassaari, K.; Ojala, S.; Stein, O.; Keiski, R.L.; Bensitel, M.; Brahmi, R. Hydrothermal Carbonization of Argan Nut Shell: Functional Mesoporous Carbon with Excellent Performance in the Adsorption of Bisphenol A and Diuron. Waste Biomass Valorization 2020, 11, 1565-1584. [CrossRef]

52. Achak, M.; Hafidi, A.; Ouazzani, N.; Sayadi, S.; Mandi, L. Low cost biosorbent "banana peel" for the removal of phenolic compounds from olive mill wastewater: Kinetic and equilibrium studies. J. Hazard. Mater. 2009, 166, 117-125. [CrossRef]

53. Xiaoli, C.; Youcai, Z. Adsorption of phenolic compound by aged-refuse. J. Hazard. Mater. 2006, B137, $410-417$. [CrossRef]

54. Özkaya, B. Adsorption and desorption of phenol on activated carbon and a comparison of isotherm models. J. Hazard. Mater. 2006, B129, 158-163. [CrossRef]

55. Fierro, V.; Tornè-Fernandez, V.; Montanè, D.; Celzard, A. Adsorption of phenols onto activated carbons having different textural and surface properties. Microporous Mesoporous Mater. 2008, 111, 276-284. [CrossRef]

56. Batool, S.; Idrees, M.; Ahmad, M.; Ahmad, M.; Hussain, Q.; Iqbal, A.; Kong, J. Design and characterization of a biomass template/ $\mathrm{SnO}_{2}$ nanocomposite for enhanced adsorption of 2,4-dichlorophenol. Environ. Res. 2020, 151, 108955. [CrossRef] [PubMed]

57. Kumar, A.; Prasad, B.; Mishra, I.M. Adsorptive removal of acrylonitrile by commercial grade activated carbon: Kinetics, equilibrium and thermodynamics. J. Hazard. Mater. 2008, 152, 589-600. [CrossRef] [PubMed]

58. IRSA-CNR 29/2003. “Metodi Analitici per le Acque" (ISBN 88-448-0083-7) vol. 2, n. 5070-A2: Fenoli. Available online: http://www.irsa.cnr.it/Docs/Capitoli/5070.pdf (accessed on 5 September 2019).

59. Burwell, R.L. Manual of Symbols and Terminology for Physicochemical Quantities and Units. IUPAC Standards Online. 1976. Available online: https://iupac.org/iupac-standards-online/ (accessed on 7 February 2020).

60. Moreno-Castilla, C. Adsorption of organic molecules from aqueous solutions on carbon materials. Carbon 2004, 42, 83-94. [CrossRef]

61. Spagnoli, A.A.; Giannakoudakis, D.A.; Bashkova, S. Adsorption of methylene blue on cashew nut shell based carbons activated with zinc chloride: The role of surface and structural parameters. J. Mol. Liq. 2017, 229, 465-471. [CrossRef]

62. Lei, S.; Miyamoto, J.; Kanoh, H.; Nakahigashi, Y.; Kaneko, K. Enhancement of the methylene blue adsorption rate for ultramicroporous carbon fiber by addition of mesopores. Carbon 2006, 44, 1884-1890. [CrossRef]

63. Çeçen, F.; Aktaş, Ö. Activated Carbon for Water and Wastewater Treatment, Integration of Adsorption and Biological Treatment; Wiley-VCH Verlag GmbH \& Co. KGaA: Weinheim, Germany, 2011.

64. Fonseca Alves, A.C.; Pacheco Antero, R.V.; Botelho de Oliveira, S.; Ojala, S.A.; Scalize, P.S. Activated carbon produced from waste coffee grounds for an effective removal of bisphenol-A in aqueous medium. Environ. Sci. Pollut. Res. 2019, 26, 24850-24862. [CrossRef]

65. Pendleton, P.; Hua Wu, S.; Badalyan, A. Activated Carbon Oxygen Content Influence on water and Surfactant Adsorption. J. Colloid Interface Sci. 2002, 246, 235-240. [CrossRef]

66. Javed, H.; Luong, D.X.; Lee, C.; Zhang, D.; Tour, J.M.; Alvarez, P.J.J. Efficient removal of bisphenol-A by ultra-high surface area porous activated carbon derived from asphalt. Carbon 2018, 140, 441-448. [CrossRef] 
67. Umar, M.; Roddick, F.; Fan, L.; Aziz, H.A. Application of ozone for the removal of bisphenol A from water and wastewater-A review. Chemosphere 2013, 90, 2197-2207. [CrossRef]

68. Fudala-Ksiazek, S.; Pierpaoli, M.; Luczkiewicz, A. Efficiency of landfill leachate treatment in a MBR/UF system combined with NF, with a special focus on phthalates and bisphenol a removal. Waste Manag. 2018, 78, 94-103. [CrossRef] [PubMed]

69. MubarakAli, D.; Park, J.; Han, T.; Srinivasan, H.; Lee, S.; Kim, J. Solution plasma process: An option to degrade bisphenol A in liquid-phase to non-toxic products. J. Mol. Liq. 2019, 276, 605-610. [CrossRef]

70. Tan, Y.H.; Goh, P.S.; Ismail, A.F. Development of photocatalytic coupled zinceiron oxide nanoparticles via solution combustion for bisphenol-A removal. Int. Biodeterior. Biodegrad. 2015, 102, 346-352. [CrossRef]

71. Supong, A.; Bhomick, P.C.; Baruah, M.; Pongener, C.; Sinha, U.B.; Sinha, D. Adsorptive removal of Bisphenol A by biomass activated carbon and insights into the adsorption mechanism through density functional theory calculations. Sustain. Chem. Pharm. 2019, 13, 100-159. [CrossRef]

72. Bautista-Toledo, I.; Ferro-Garcia, M.A.; Rivero Utrilla, J.; Moreno Castilla, C.; Vegas Fernandez, F.J. Bisphenol A removal from water by activated carbon. Effects of carbon characteristics and solution chemistry. Environ. Sci. Technol. 2005, 39, 6246-6250. [CrossRef] [PubMed]

(C) 2020 by the authors. Licensee MDPI, Basel, Switzerland. This article is an open access article distributed under the terms and conditions of the Creative Commons Attribution (CC BY) license (http://creativecommons.org/licenses/by/4.0/). 